\title{
IDENTIFIKASI KESULITAN SISWA DALAM MENYELESAIKAN SOAL-SOAL HIDROLISIS GARAM MENGGUNAKAN LANGKAH PENYELESAIAN SOAL
}

\author{
Muh. Iqbal Fitranda, Muntholib ${ }^{1}$ \\ 1. Jurusan Kimia Universitas Negeri Malang
}

\begin{abstract}
Abstrak - Hidrolisis garam termasuk materi pelajaran kimia yang kompleks yang sulit dipahami oleh sebagian siswa. Penelitian ini dilakukan untuk mengetahui letak kesulitan siswa dalam menyelesaian soal-soal hidrolisis garam. Penelitian ini menggunakan rancangan penelitian deskriptif kuantitatif. Subjek penelitian ini adalah 72 siswa kelas XI SMAN 9 Malang yang telah belajar hidrolisis garam. Instrumen penelitian ini adalah tes algoritmik terbuka yang terdiri atas 10 butir soal yang valid dengan Cronbach's Alpha reliability coefficient sebesar 0,713 . Hasil analisis menunjukkan bahwa tingkat kesulitan siswa dalam menyelesaikan soal-soal tes hidrolisis garam adalah $26,80 \%$ dengan kategori rendah.
\end{abstract}

Kata kunci: kesulitan siswa, bidrolisis garam, langkah penyelesaian soal

\begin{abstract}
The topic of salt hydrolysis is a complex chemistry subject that is difficult for some students to understand. This research was conducted to determine the students' difficulties in solving salt hydrolysis problems. This research uses descriptive quantitative research design. The subjects of this study were 72 grade XI students of SMAN 9 Malang who had learned salt hydrolysis. The research instrument was an open-ended test consisting of 10 valid items with Cronbach's Alpha reliability coefficient of 0.713 . The results of the analysis showed that the level of students' difficulty in solving salt hydrolysis problems was $26.80 \%$ with low category.
\end{abstract}

Keywords: students' difficulty, salt bydrolysis, problem solving

\section{PENDAHULUAN}

Sains merupakan ilmu yang menarik bagi pebelajar karena fenomenanya bisa diamati secara langsung dari lingkunglan sekitar. Sebagai bagian dari Sains, fenomena Kimia juga banyak ditemukan dalam kehidupan sehari-hari. Kimia adalah ilmu yang mempelajari penyusun, komposisi dan sifat materi serta perubahan dan energi yang menyertai perubahan materi (Chang \& Goldsby, 2016; Fay et al., 2012). Konsekuensinya, bahan kajian Kimia mengandung konsepkonsep yang abstrak dan kompleks yang tidak bisa dipahami dengan simbol-simbol, pengertianpengertian, dan teori-teori saja. Konsep-konsep Kimia yang abstrak perlu direpresentasikan ke dalam representasi yang mudah dipahami (Chiu, 2007), termasuk di dalamnya konsep-konsep hidrolisis garam.

Bahan kajian Hidrolisis Garam mengandung konsep-konsep yang abstrak, kompleks, dan sulit dipahami karena terkait dengan konsep-konsep bahan kajian lain. Untuk memahami konsepkonsep hidrolisis garam, siswa harus memahami konsep-konsep asam-basa, kesetimbangan asambasa, disosiasi ion-ion penyusun garam, dan sifat-sifat reaktan dan produk yang berhubungan

\footnotetext{
${ }^{1}$ Corresponding author: Jurusan Kimia Universitas Negeri Malang. Email: muntholib.fmipa@um.ac.id
} 
dengan hidrolisis garam (Orwat et al., 2017; Seçken, 2010). Siswa tidak bisa memahami dengan baik, mengapa garam $\mathrm{CH}_{3} \mathrm{COONa}$ mengalami hidrolisis parsial sebelum dia memahami kesetimbangan ionisasi $\mathrm{CH}_{3} \mathrm{COOH}$ dan disosiasi sempurna $\mathrm{NaOH}$.

Di samping dipengaruhi oleh konsep-konsep bahan kajian lain, bahan kajian Hidrolisis Garam juga mempengaruhi pemahaman siswa terhadap bahan kajian yang lain, misalnya larutan penyangga, kelarutan garam, dan hasil kali kelarutan. Oleh karena itu, pemahaman siswa terhadap atau kesulitan mereka dalam memahami konsep-konsep dasar hidrolisis garam perlu diketahui dengan baik. Terungkapnya kesulitan siswa dalam memahami konsep-konsep dasar hidrolisis garam atau menyelesaikan soal-soalnya memudahkan guru dalam merancang pembelajaran yang bisa digunakan untuk memecahkan kesulitan siswa.

Penyelesaian soal hidrolisis garam membutuhkan langkah-langkah algoritmik yang harus diikuti. Namun demikian, sampai saat ini kami belum menemukan kajian tentang soal-soal hidrolisis garam algoritmik dan kesulitan siswa dalam menyelesaikannya. Teridentifikasinya kesulitan siswa dalam menyelesaikan soal-soal algoritmik dapat membantu guru dalam merancang strategi pembelajaran yang lebih baik. Tujuan penelitian ini adalah mengevaluasi kesulitan siswa dalam menyelesaikan soal-soal algoritmik hidrolisis garam.

\section{METODE}

Penelitian ini merupakan penelitian deskriptif yang mendeskripsikan kesulitan siswa dalam menyelesaikan soal-soal hidrolisis garam. Subjek penelitian ini adalah siswa kelas XI SMAN 9 Malang.

\section{Instrumen}

Instrumen penelitian berupa soal-soal algoritmik hidrolisis garam yang terdiri atas 10 butir soal. Pengembangan tes mengikuti prosedur yang telah digunakan oleh para peneliti sebelumnya (Chandrasegaran et al., 2007; Damanhuri et al., 2016; Muntholib et al., 2020; Nugraha et al., 2020). Validasi konstruk dan konten menunjukkan bahwa instrumen berkategori sangat baik (skor rata-rata penilaian validator adalah 92,86\%). Sedangkan uji coba lapangan menunjukkan bahwa soal-soal tes ini adalah valid dengan Cronbach's Alpha reliability coefficient sebesar 0,713, berada di atas harga yang bisa diterima untuk kepentingan penelitan, yakni 0,70 (Fraenkel et al., 2018; Kimberlin \& Winterstein, 2008; Taber, 2018; van Griethuijsen et al., 2015).

\section{Analisis Data}

Respon siswa terhadap setiap langkah penyelesaian soal kemudian dikategorikan ke dalam dua tingkat jawaban, benar dan salah. Skor-skor responden kemudian diurutkan dari yang tertinggi ke yang terendah. Sesuai dengan skor tesnya, siswa kemudian diklasifikasikan menjadi 3 kelompok, yaitu kelompok atas, kelompok menengah dan kelompok bawah. Analisis tingkat kesulitan siswa dalam menyelesaikan soal-soal hidrolisis garam dilakukan dengan dua pendekatan, pendekatan bahan kajian dan pendekatan langkah-langkah penyelesaian soal. Kami mengidentifikasi tiga bahan kajian hidrolisis garam, yaitu jenis-jenis hidrolisis, sifat larutan garam hasil hidrolisis, dan $\mathrm{pH}$ larutan hasil hidrolisis. Dalam kaitannya dengan penyelesaian soal-soal hidrolisis garam, kami mengidentifikasi 14 langkah penyeselasian (Tabel 1). Setiap soal memerlukan sejumlah langkah tertentu dalam penyelesaiannya. Soal yang berbeda bisa memerlukan jenis dan jumlah langkah yang berbeda pula. Dengan kata lain, setiap soal memerlukan langkah penyelesaiannya sendiri. 
Tabel 1. 14 Langkah Penyelesaian Soal Hidrolisis Garam

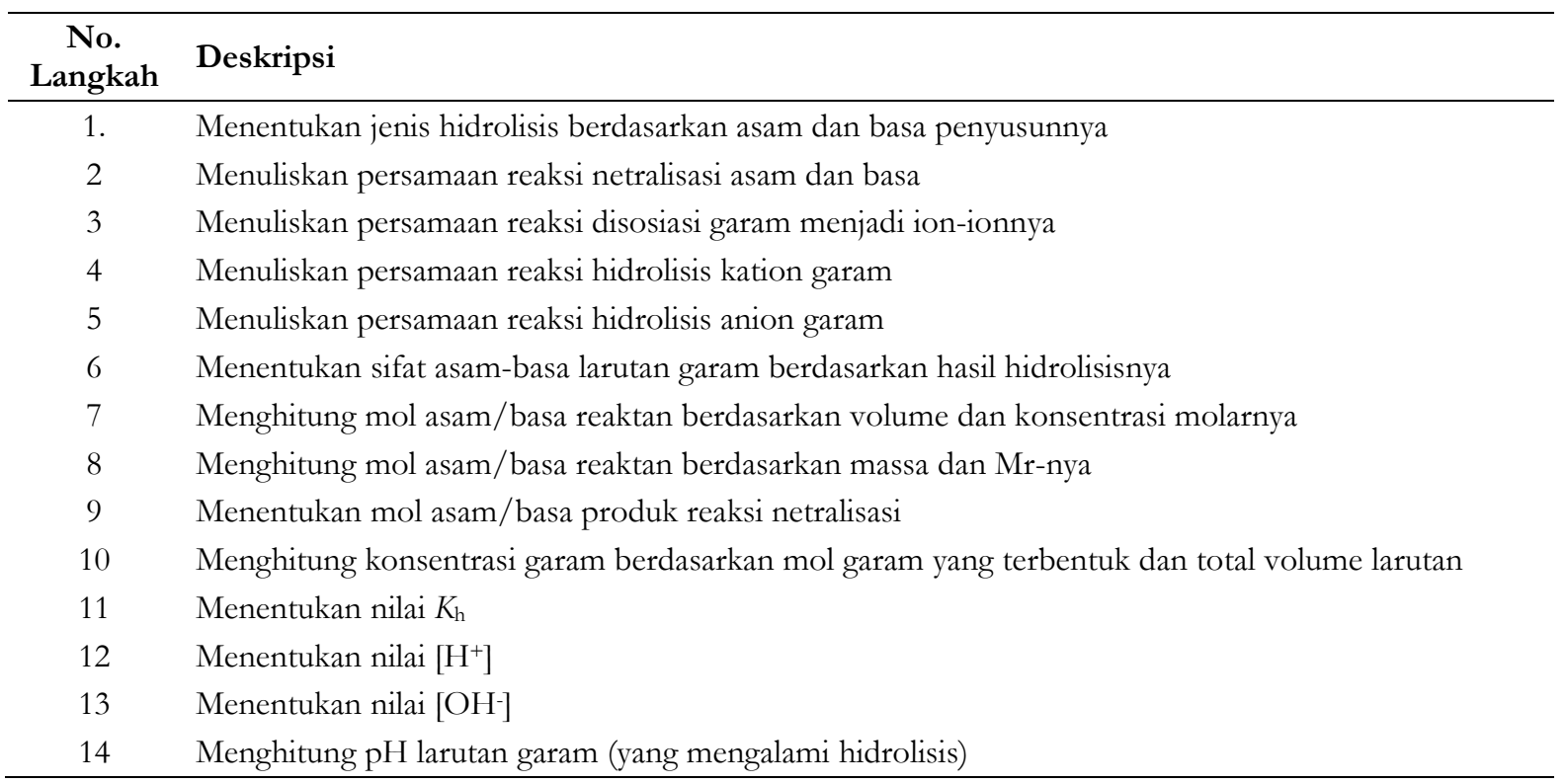

Tingkat kesulitan setiap kelompok siswa dalam menyelesaikan soal-soal hidrolisis garam dihitung dengan persamaan:

Keterangan:

$$
\mathrm{P}=(\mathrm{S} / \mathrm{N}) \times 100 \%
$$

$\mathrm{P}=$ Persentase siswa yang mengalami kesulitan

$\mathrm{S}=$ Jumlah siswa menjawab salah

$\mathrm{N}=$ Jumlah siswa seluruhnya

Sedangkan pengkategorian tingkat kesulitan siswa dalam menyelesaikan soal-soal hidrolisis garam dilakukan berdasarkan kriteria Tabel 2 (Heng et al., 2014).

Tabel 2. Kriteria Tingkat Kesulitan Siswa

\begin{tabular}{ll}
\hline Persentase Kesulitan & Kategori \\
\hline $0,00-19,00 \%$ & Sangat Rendah \\
$20,00-39,99 \%$ & Rendah \\
$40,00-59,99 \%$ & Sedang \\
$60,00-79,00 \%$ & Tinggi \\
$80,00-100 \%$ & Sangat Tinggi \\
\hline
\end{tabular}

\section{HASIL DAN PEMBAHASAN}

Untuk keperluan analisis, 72 orang subjek penelitian diklasifikasikan ke dalam tiga kelompok sesuai dengan capaikan akademiknya, 24 siswa diklasifikasikan ke dalam kelompok atas (KA), 24 siswa kelompok menengah (KM), dan 24 siswa kelompok bawah (KB). Analisis tingkat kesulitan siswa dalam menyelesaikan soal-soal hidrolisis garam, baik berdasarkan bahan kajian maupun berdasarkan langkah-langkah penyelesaian soal, dilakukan pada tiga kelompok siswa ini.

\section{Tingkat Kesulitan Siswa Berdasarkan Bahan Kajian Hidrolisis Garam}

Tingkat kesulitan siswa dalam menyelaikan soal-soal bahan kajian hidrolisis garam disajikan pada Tabel 3 . 
Tabel 3. Tingkat Kesulitan Siswa dalam Menyelesaikan Soal-soal Bahan Kajian Hidrolisis Garam

\begin{tabular}{|c|c|c|c|c|c|c|c|c|c|}
\hline \multirow{2}{*}{ No. } & \multirow{2}{*}{ Bahan Kajian } & \multicolumn{6}{|c|}{$\%$ Siswa yang Menjawab Salah } & \multirow{2}{*}{ Rerata } & \multirow{2}{*}{ Kat } \\
\hline & & KA & Kat. & $\mathrm{KM}$ & Kat. & $\mathrm{KB}$ & Kat. & & \\
\hline 1 & $\begin{array}{l}\text { Jenis-jenis Hidrolisis } \\
\text { Garam }\end{array}$ & 4,2 & SR & 13,9 & SR & 38,9 & $\mathrm{R}$ & 19 & SR \\
\hline 2 & $\begin{array}{l}\text { Sifat Larutan Garam } \\
\text { Hasil Hidrolisis }\end{array}$ & 7,9 & SR & 18,1 & SR & 27,8 & $\mathrm{R}$ & 17,9 & SR \\
\hline 3 & $\begin{array}{l}\text { pH Larutan Garam } \\
\text { Hasil Hidrolisis }\end{array}$ & 18,9 & SR & 45,7 & S & 65,7 & $\mathrm{~T}$ & 43,5 & S \\
\hline \multicolumn{2}{|c|}{ Rata-rata } & 10,3 & SR & 25,9 & $\mathrm{R}$ & 44,1 & S & 26,8 & $\mathrm{R}$ \\
\hline
\end{tabular}

KA: Kelompok Atas; KM: Kelompok Menengah; KB : Kelompok Bawah; SR: Sangat Rendah; R: Rendah; S: Sedang; T: Tinggi; ST: Sangat Tinggi

Tabel 3 menunjukkan bahwa (1) subjek penelitian tidak kesulitan mengidentifikasi jenis hidrolisis (total, parsial, atau tidak mengalami hidrolisis) dan menentukan sifat larutan hasil hidrolisis (asam, basa, atau netral), tetapi cukup kesulitan menghitung $\mathrm{pH}$ larutan hasil hidrolisis; dan (2) meskipun tidak mengalami kesulitan mengidentifikasi jenis hidrolisis dan menentukan sifat larutan hasil hidrolisis, subjek penelitian kelompok atas dan mengengah lebih mudah mengidentifikasi jenis hidrolisis dari pada menentukan sifat larutan hasil hidrolisis, sebaliknya subjek penelitian kelompok bawah lebih sulit mengidentifikasi jenis hidrolisis dari pada menentukan sifat larutan hasil hidrolisis.

\section{Tingkat Kesulitan Siswa Berdasarkan Langkah Penyelesaian Soal-soal}

Tingkat kesulitan siswa dalam menyelaikan langkah-langkah penyelesaian soal hidrolisis garam disajikan pada Tabel 4.

Tabel 4. Tingkat kesulitan siswa dalam menyelaikan langkah-langkah penyelesaian soal hidrolisis garam

\begin{tabular}{|c|c|c|c|c|c|c|}
\hline \multirow{2}{*}{ No. } & \multirow{2}{*}{ Langkah Penyelesaian } & \multicolumn{3}{|c|}{ Tingkat Kesulitan (\%) } & \multirow{2}{*}{ Rerata } & \multirow{2}{*}{ Kategor } \\
\hline & & KA & KM & KB & & \\
\hline 1. & $\begin{array}{l}\text { Menentukan jenis hidrolisis berdasarkan asam } \\
\text { dan basa penyusunnya }\end{array}$ & 4,2 & 13,9 & 38,9 & 19 & SR \\
\hline 2. & $\begin{array}{l}\text { Menuliskan persamaan reaksi netralisasi asam } \\
\text { dan basa }\end{array}$ & 14,6 & 47,9 & 59,4 & 40,6 & S \\
\hline 3. & $\begin{array}{l}\text { Menuliskan persamaan reaksi disosiasi garam } \\
\text { menjadi ion-ionnya }\end{array}$ & 16,7 & 31,3 & 29,2 & 25,7 & $\mathrm{R}$ \\
\hline 4. & $\begin{array}{l}\text { Menuliskan persamaan reaksi hidrolisis kation } \\
\text { garam }\end{array}$ & 4,2 & 14,6 & 33,3 & 17,4 & SR \\
\hline 5. & $\begin{array}{l}\text { Menuliskan persamaan reaksi hidrolisis anion } \\
\text { garam }\end{array}$ & 6,3 & 14,6 & 29,2 & 16,7 & SR \\
\hline 6. & $\begin{array}{l}\text { Menentukan sifat asam-basa larutan garam } \\
\text { berdasarkan hasil hidrolisisnya }\end{array}$ & 6,3 & 18,8 & 29,2 & 18,1 & SR \\
\hline 7. & $\begin{array}{l}\text { Menghitung mol asam/basa reaktan } \\
\text { berdasarkan volume dan konsentrasi } \\
\text { molarnya }\end{array}$ & 11,1 & 34,7 & 50 & 31,9 & $\mathrm{R}$ \\
\hline 8. & $\begin{array}{l}\text { Menghitung mol asam/basa reaktan } \\
\text { berdasarkan massa dan Mr-nya }\end{array}$ & 6,9 & 22,2 & 55,6 & 28,2 & $\mathrm{R}$ \\
\hline 9. & $\begin{array}{l}\text { Menentukan mol asam/basa produk reaksi } \\
\text { netralisasi }\end{array}$ & 18,1 & 59,7 & 70,8 & 49,5 & S \\
\hline 10. & $\begin{array}{l}\text { Menghitung konsentrasi garam berdasarkan } \\
\text { mol garam yang terbentuk dan total volume } \\
\text { larutan }\end{array}$ & 22,2 & 43,1 & 75 & 46,8 & S \\
\hline
\end{tabular}




\begin{tabular}{llccccc}
\hline \multirow{2}{*}{ No. } & \multirow{2}{*}{ Langkah Penyelesaian } & \multicolumn{3}{c}{ Tingkat Kesulitan (\%) } & \multirow{2}{*}{ Rerata } & \multirow{2}{*}{ Kategori } \\
& & KA & KM & KB & & \\
\hline 11. & Menentukan nilai $\mathrm{K}_{\mathrm{h}}$ & 3,1 & 33,3 & 54,2 & 30,2 & $\mathrm{R}$ \\
12. & Menentukan konsentrasi ion $\mathrm{H}^{+}$ & 27,8 & 70,8 & 77,8 & 58,8 & $\mathrm{~S}$ \\
13. & Menentukan konsentrasi ion $\mathrm{OH}^{-}$ & 0 & 4,2 & 54,2 & 19,4 & $\mathrm{SR}$ \\
14. & Menghitung pH larutan garam (yang & 46,9 & 54,2 & 71,9 & 57,6 & $\mathrm{~S}$ \\
& mengalami hidrolisis) & & & & & \\
\hline
\end{tabular}

Tabel 4 menunjukkan bahwa: (1) tiga langkah yang tingkat kesulitannya paling rendah adalah "menuliskan persamaan reaksi hidrolisis anion garam" dengan tingkat kesulitan 16,7 (sangat rendah), "menuliskan persamaan reaksi hidrolisis kation garam" dengan tingkat kesulitan 17,40 (sangat rendah), dan "menentukan sifat asam-basa larutan garam berdasarkan hasil hidrolisisnya" dengan tingkat kesulitan 18,1 (sangat rendah); (2) tiga langkah yang tingkat kesulitannya paling tinggi adalah "menentukan konsentrasi ion $\mathrm{H}^{+}$" dengan tingkat kesulitan 58,8 (sedang mendekati tinggi), "menghitung $\mathrm{pH}$ larutan garam (yang mengalami hidrolisis)" dengan tingkat kesulitan 57,60 (sedang mendekati tinggi), dan "enentukan mol asam/basa produk reaksi netralisasi" dengan tingkat kesulitan 49,5 (sedang); dan (3) langkah yang tingkat kesulitannya tinggi berbeda antara siswa kelompok atas, kelompok menengah, dan kelompok bawah.

\section{PEMBAHASAN}

\section{Tingkat Kesulitan Bahan Kajian Hidrolisis Garam}

Subjek penelitian tidak mengalami kesulitan dalam mengidentifikasi jenis hidrolisis yang dialami suatu garam dan menentukan sifat asam-basa larutan hasil hidrolisisnya, tetapi cukup kesulitan dalam menghitung $\mathrm{pH}$ larutan hasil hidrolisis.

Tingkat kesulitan siswa dalam menentukan jenis-jenis hidrolisis garam (tidak mengalami hidrolisis, mengalami hidrolisis parsial, dan mengalami hidrolisis total) sangat rendah dengan pola yang logis, banyaknya siswa kelompok atas yang mengalami kesulitan $(4,2 \%)$, lebih rendah dari pada siswa kelompok menengah $(13,9 \%$ ), dan lebih rendah dari pada siswa kelompok bawah $(38,9 \%)$. Ini mengindikasikan pembelajaran sudah berjalan dengan baik. Namun demikian, adanya siswa yang menganggap bahwa $\mathrm{HCN}$ sebagai asam kuat sehingga $\mathrm{NaCN}$ tidak mengalami hidrolisis dan $\mathrm{NH}_{4} \mathrm{Cl}$ mengalami hidrolisis total sehingga $\mathrm{HCl}$ sebagai asam lemah perlu mendapatkan perhatian. Hal ini tidak berarti siswa mengalami alternative conception atau misconception (Brandriet \& Bretz, 2014; Chandrasegaran et al., 2007; Damanhuri et al., 2016), tetapi lebih menggambarkan cara belajar rote learning (menghafal) dari pada mastery learning (belajar tuntas) (Gallagher, 1998).

Tingkat kesulitan siswa dalam menentukan sifat larutan garam hasil hidrolisis (asam, basa, atau netral) lebih rendah dari pada tingkat kesulitan mereka dalam menentukan jenis-jenis hidrolisis garam. Menurut pandangan mastery learning (Guskey, 2012), siswa mudah memahami konsep hidrolisis garam dari pada konsep sifat larutan hasil hidrolisis garam. Sifat larutan hasil hidrolisis garam merupakan akibat terjadinya hidrolisis. Logikanya, siswa tidak bisa memprediksi sifat laturan hasil hidrolisis garam sebelum tahu bagaimana garam tersebut mengalami hidrolisis. Temuan ini mengokohkan dugaan bahwa pembelajaran berjalan dengan cara siswa menghafal fakta-fakta, konsep-konsep, hukum-hukum, dan teori-teori.

Sebagian siswa mengalami kesalahan dalam menentukan sifat larutan garam $\mathrm{NH}_{4} \mathrm{NO}_{3}$ dan $\mathrm{KCN}$. Siswa yang memahami konsep kekutan asam-basa dengan baik tentu tidak sulit menentukan kekuatan asam-basa $\mathrm{NH}_{3}, \mathrm{KOH}, \mathrm{HCN}$, dan $\mathrm{HNO}_{3}$ yang merupakan pembentuk garam-garam $\mathrm{NH}_{4} \mathrm{NO}_{3}$ dan KCN. Kekuatan asam-basa senyawa-senyawa tersebut tergambar dengan jelas di harga $K_{\mathrm{a}}$ atau $K_{\mathrm{b}}$-nya. Bisa juga dilihat dari $\mathrm{pH}$ larutannya pada konsentrasi tertentu. Bahkan bisa juga dilihat dari daftar asam-basa kuat atau lemah. Oleh karena itu, siswa yang memahami konsep 
hidrolisis garam dengan baik, tidak mengalami kesulitan menentukan sifat asam-basa larutan garam yang mengalami hidrolisis.

Tingkat kesulitan siswa dalam menentukan $\mathrm{pH}$ larutan garam hasil hidrolisis tergolong menengah dengan persentase rata-rata 43,5\%. Artinya, hampir separuh siswa mengalami kesulitan dalam menentukan $\mathrm{pH}$ larutan garam hasil hidrolisis. Bahkan tingkat kesulitan siswa kelompok bawah mencapai 65,7\% dengan kategori tinggi. Temuan ini bisa dipahami dan sekaligus sebagai petunjuk bahwa pembelajaran kimia, dalam hal ini penentuan $\mathrm{pH}$ larutan garam hasil hidrolisis, tidak hanya memerlukan pemahaman, tetapi juga memerlukan strategi metakognisi (Aleven \& Koedinger, 2002) dan kecerdasan matematika (Albaladejo et al., 2018).

\section{Tingkat Kesulitan Langkah Penyelesaian Soal Hidrolisis Garam}

Secara keseluruhan, siswa tidak banyak menemukan kesulitan dalam menyelesaikan langkahlangkah penyelesaian soal-soal hidrolisis garam. Bahkah siswa kelompok atas hampir tidak menemui kesulitan keculai yang berhubungan dengan matematika. Berikut adalah penjelasan temuan-temuan penting penelitian ini.

\section{Siswa Tidak Kesulitan Menyelesaikan Soal Konseptual}

Enam langkah pertama penyelesaian soal-soal hisrolisis garam bersifat konseptual. Siswa nyaris tidak menemukan kesulitan dalam menyelesaikan ke enam langkah ini. Tingkat kesulitan penyelesaian langkah-langkah tersebut berkisar antara sangat rendah dan rendah keculai langkah ke dua, yakni "menuliskan persamaan reaksi netralisasi asam dan basa." Tingkat kesulitan penyelesaian langkah ke dua tersebut berkategori sedang dengan tingkat kesulitan rata-rata $40,60 \%$. Temuan ini tentu sangat mengagetkan mengingat netralisasi asam basa merupakan konsep dasar kimia asam-basa yang melandasi konsep-konsep kimia yang lain seperti titrasi asambasa dan hidrolisis garam. Bisa jadi, kesulitan ini disebabkan oleh pembelajaran kimia asam-basa yang lebih fokus pada sifat asam-basa, konsentrasi, dan penentukan konsentrasi dan $\mathrm{pH}$ larutan. Kesulitan ini perlu diatasi dengan menerapkan mastery learning dengan baik di mana pembelajaran baru bisa dilanjutkan bila pemehaman siswa terhadap pengetahuan prasyarat mencapai 90\% (Gallagher, 1998; Levine, 1985). Artinya, apersepsi (Gagné, 2005; Ilie, 2014) yang dilakukan guru sebelum melanjutkan pembelajaran hendaknya berupa validasi terhadap pemahaman pengetahuan prasyarat siswa.

\section{Siswa Mengalami Kesulitan Menyelesaikan Soal Matematika Kimia}

Penyelesaian langkah ke 7 sampai dengan langkah ke 14 dari 14 langkah penyelesaian soal-soal hidrolisis garam memerlukan keterampilan matematika. Tingkat kesulitan siswa dalam menyelesaikan langkah-langkah ini berkisar antara kategori rendah hingga sedang, kecuali langkah ke 13, yakni menentukan konsentrasi ion $\mathrm{OH}^{-}$, yang berkategori sangat rendah. Rendahnya tingkat kesulitan siswa dalam menyelesaikan langkah ini bisa jadi disebabkan oleh terbatasnya varian soal penentuan konsentrasi ion $\mathrm{OH}^{-}$. Di buku-buku SMA, pembahasan tentang basa tidak beranjak dari $\mathrm{NaOH}, \mathrm{KOH}$, dan $\mathrm{NH}_{3}$. Oleh karena itu soal-soal tentang basa dan konsentrasi basa sudah menjadi pengetahuan yang sudah tersimpan di memori siswa dan tinggal mengingat (Anderson \& Krathwohl, 2001) bila diperlukan.

Dari keseluruhan 14 langkah tersebut dua langkah di mana siswa paling mengalami kesulitan adalah langkah ke 12, yakni "menentukan konsentrasi ion $\mathrm{H}^{+}$", dengan tingkat kesulitan 58,80\% (sedang mendekati tinggi), dan langkah ke 14, yakni "menghitung $\mathrm{pH}$ larutan garam (yang mengalami hidrolisis)" dengan tingkat kesulitan 57,60\% (sedang mendekati tinggi). Sebenarnya langkah ke 14 sangat mudah, hanya memasukkan besaran konsentrasi ion $\mathrm{H}^{+}$ke dalam persamaan $\mathrm{pH}=-\log \left[\mathrm{H}^{+}\right]$. Namun demikian, penyelesaian langkah ini harus melewati langkah ke 14 yang sulit yakni menentukan konsentrasi ion $\mathrm{H}^{+}$. Langkah ini merupakah langkah tersulit dari keseluruhan langkah penyelesaian soal-soal hidrolisis garam yang dimulai dari penulisan reaksi ionisasi garam, menentukan spesi ion yang mengalami hidrolisis, menentukan 
konsentrasinya, menentukan konsentrasi ion $\mathrm{H}^{+}$yang dihasilkan dan yang terakhir menghitung pH-nya. Penyelesaian soal ini memerlukan pemahaman konsep-konsep garam, hidrolisis garam dan kekuatan asam-basa yang baik, strategi metakognisi (Aleven \& Koedinger, 2002) dan keterampilan matematika kimia (Albaladejo et al., 2018). Oleh karena itu wajar apabila tingkah kesulitan rata-rata siswa berada pada kategori sedang mendekati tinggi.

\section{KESIMPULAN}

Siswa tidak mengalami kesulitan dalam menyelesaikan soal-soal hidrolisis garam yang bersifat konseptual, tetapi mengalami kesulitan dalam menyelesaikan soal-soal yang penyelesaiannya memerlukan strategi metakognisi dan matematika kimia yang tinggi. Namun demikian, ada indikasi bahwa pembelajaran konseptual siswa tidak tuntas. Oleh karena itu disarankan bahwa pembelajaran hendaknya memperhatikan pengembangan strategi metakognisi dan keterampilan matematika kimia siswa. Di samping itu, langkah pendahuluan/apersepsi dan penutupan hendaknya memperhatikan pandangan mastery learning dalam pembelajaran.

\section{DAFTAR RUJUKAN}

Albaladejo, J. D. P., Broadway, S., Mamiya, B., Petros, A., Powell, C. B., Shelton, G. R., Walker, D. R., Weber, R., Williamson, V. M., \& Mason, D. (2018). ConfChem Conference on Mathematics in Undergraduate Chemistry Instruction: MUST-Know Pilot Study-Math Preparation Study from Texas. Journal of Chemical Education, 95(8), 1428-1429. https://doi.org/10.1021/acs.jchemed.8b00096

Aleven, V. A. W. M. M., \& Koedinger, K. R. (2002). An effective metacognitive strategy: Learning by doing and explaining with a computer-based Cognitive Tutor. Cognitive Science, 26(2), 147-179. https://doi.org/10.1207/s15516709cog2602_1

Anderson, L. W., \& Krathwohl, D. R. (Eds.). (2001). A taxonomy for learning, teaching, and assessing: A revision of Bloom's taxonomy of educational objectives (Complete ed). Longman.

Brandriet, A. R., \& Bretz, S. L. (2014). The Development of the Redox Concept Inventory as a Measure of Students' Symbolic and Particulate Redox Understandings and Confidence. Journal of Chemical Education, 91(8), 1132-1144. https://doi.org/10.1021/ed500051n

Chandrasegaran, A. L., Treagust, D. F., \& Mocerino, M. (2007). The development of a two-tier multiple-choice diagnostic instrument for evaluating secondary school students' ability to describe and explain chemical reactions using multiple levels of representation. Chem. Educ. Res. Pract., 8(3), 293-307. https://doi.org/10.1039/B7RP90006F

Chang, R., \& Goldsby, K. A. (2016). Chemistry (Twelfth edition). McGraw-Hill Education.

Chiu, M. (2007). A National Survey of Students' Conceptions of Chemistry in Taiwan. International Journal of Science Education, 29(4), 421-452. https://doi.org/10.1080/09500690601072964

Damanhuri, M. I. M., Treagust, D. F., Won, M., \& Chandrasegaran, A. L. (2016). High School Students' Understanding of Acid-Base Concepts: An Ongoing Challenge for Teachers. The International Journal of Environmental and Science Education. https://doi.org/10.12973/ijese.2015.284a

Fay, R., McMurry, J., \& Fantini, J. (2012). Chemistry. In Vasa.

Fraenkel, J. R., Wallen, N. E., \& Hyun, H. H. (2018). How to design and evaluate research in education (Tenth edition). McGraw-Hill Education.

Gagné, R. M. (Ed.). (2005). Principles of instructional design (5th ed). Thomson/Wadsworth. 
Gallagher, S. A. (1998). The Road to Critical Thinking: The Perry Scheme and Meaningful Differentiation. NASSP Bulletin, 82(595), 12-20. https://doi.org/10.1177/019263659808259504

Guskey, T. R. (2012). Mastery Learning. In N. M. Seel (Ed.), Encyclopedia of the Sciences of Learning (pp. 2097-2100). Springer US. https://doi.org/10.1007/978-1-4419-1428-6_1553

Heng, L. L., Surif, J., \& Seng, C. H. (2014). Individual Versus Group Argumentation: Student's Performance in a Malaysian Context. International Education Studies, 7(7), p109. https://doi.org/10.5539/ies.v7n7p109

Ilie, M. D. (2014). An adaption of Gagné's instructional model to increase the teaching effectiveness in the classroom: The impact in Romanian Universities. Educational Technology Research and Development, 62(6), 767-794. https://doi.org/10.1007/s11423-014-9353-6

Kimberlin, C. L., \& Winterstein, A. G. (2008). Validity and reliability of measurement instruments used in research. American Journal of Health-System Pharmacy, 65(23), 2276-2284. https://doi.org/10.2146/ajhp070364

Levine, D. U. (1985). Improving student achievement through mastery learning programs (1st ed). Jossey-Bass.

Muntholib, M., Ibnu, S., Rahayu, S., Fajaroh, F., Kusairi, S., \& Kuswandi, B. (2020). Chemical Literacy: Performance of First Year Chemistry Students on Chemical Kinetics. Indonesian Journal of Chemistry, 20(2), 468-482. https://doi.org/10.22146/ijc.43651

Nugraha, V. D., Muntholib, M., Joharmawan, R., Parlan, P., Yahmin, Y., \& Su'aidy, M. (2020). The development of the acid-base chemistry test oriented to higher order thinking skills for 11 th grade students. 020015. https://doi.org/10.1063/5.0000546

Orwat, K., Bernard, P., \& Migda \l-Mikuli, A. (2017). Alternative conceptions of common salt hydrolysis among upper-secondary-school students. In Journal of Baltic Science Education (Vol. 16, p. Continuous).

Seçken, N. (2010). Identifying Student's Misconceptions about SALT. Procedia - Social and Behavioral Sciences, 2(2), 234-245. https://doi.org/10.1016/j.sbspro.2010.03.004

Taber, K. S. (2018). The Use of Cronbach's Alpha When Developing and Reporting Research Instruments in Science Education. Research in Science Education, 48(6), 1273-1296. https://doi.org/10.1007/s11165-016-9602-2

van Griethuijsen, R. A. L. F., van Eijck, M. W., Haste, H., den Brok, P. J., Skinner, N. C., Mansour, N., Savran Gencer, A., \& BouJaoude, S. (2015). Global Patterns in Students' Views of Science and Interest in Science. Research in Science Education, 45(4), 581-603. https://doi.org/10.1007/s11165-014-9438-6 